岡山大学医学部, 解剖学敉公 (主任: 関呚授).

Anat. Inst. d. Med. Fak., Univ. Okayama (Direktor: Prof. M. SEKI).

\title{
二十日鼠の皮膚と脂腺の脂肪と類脂質の觀察.
}

\section{Beobachtung des Fettes und der Lipoide der Haut und Talgdrüsen der Maus.}

\section{壹 岐 寬 治 Kanji IKI.}

[昭和 28 年 1 月 9 日原稿受附.]

動物の皮嗍之脂腺の脂肪之特に類㸟質を自然に近い狀態で組織学的に篗

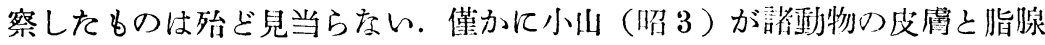
のコレステリンに注意し, Walter (1924), 山口（大13）等が主に脂腺の

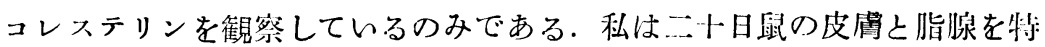
に神山（昭 25，26a，b）が推獎した中等極性でアルコール溶性の染料の ビクトリア青で染めて類脂質の状態を檢べ，新しく種々の事実を知ること ができた.

\section{I. 材料と方法.}

健常の成熟…ㅂ日鼠の背部の皮膚を一部切出し，10\%ホルマリンに 1

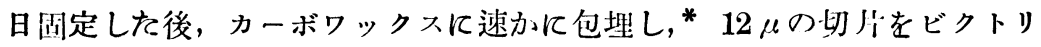

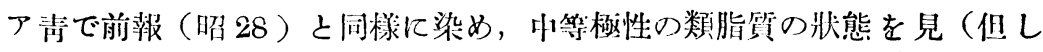
㤥年赤で軽く後染色する)，また無極性の脂肪は無極性のズダンIII で染め て観祭した（このときはへマトキシリンで後染）.

次に生きた…1日鼠の全身の毛を短く刘り， $37^{\circ} \mathrm{C} の 5,000$ 倍ビクトリ ア青浴液に浸し表皮の青染の部位的㴦異を調べた。

\section{II. 所見亡考察.}

\footnotetext{
*人は普通カーボワックスを約 $54^{\circ} \mathrm{C}$ に融して用 いるが，かくては問題の脂脏と頪脂斦が溶出する 惧れがあるから；ここでは注意して $45^{\circ}-50^{\circ} \mathrm{C}$ 出好よらにした。參考のために右に種々の溫度の カーボワックスにレチチンと大風子油が溶ける程度 を表示する・一は不溶，士は一部溶解，十は溶解。 即ち上記のよらにカーボワックスを包埋料として使 用すれば少くもレチチンはその䀀度には溶けずし て，組織附に保存せられる䍃である。
}

\begin{tabular}{c|c|c}
\hline & レチチン & 大風子油 \\
\hline $52^{\circ}$ & - & - \\
$55^{\circ}$ & - & \pm \\
$57^{\circ}$ & - & \pm \\
$60^{\circ}$ & - & \pm \\
$62^{\circ}$ & - & + \\
$65^{\circ}$ & \pm & + \\
$70^{\circ}$ & + & +
\end{tabular}




\section{A. 固定組織切片の染色.}

1. 脂腺之毛.

脂腺の腺胞の細胞はすべて㤥华赫で薄赤く染り，少しもビクトリア青に 染らない。しかし毛包の上皮の毛に向う面と电の袁面には青染する物質が 附着して居り（図 1 己2）、よく見れば青染する物質は多少毛包上皮內に 滲达んで居り，乙れは特に甩包が斜衒せられた図 2 に明かである。但しも 包も洰も脂腺の閁口よりも深くある部では青染しない。

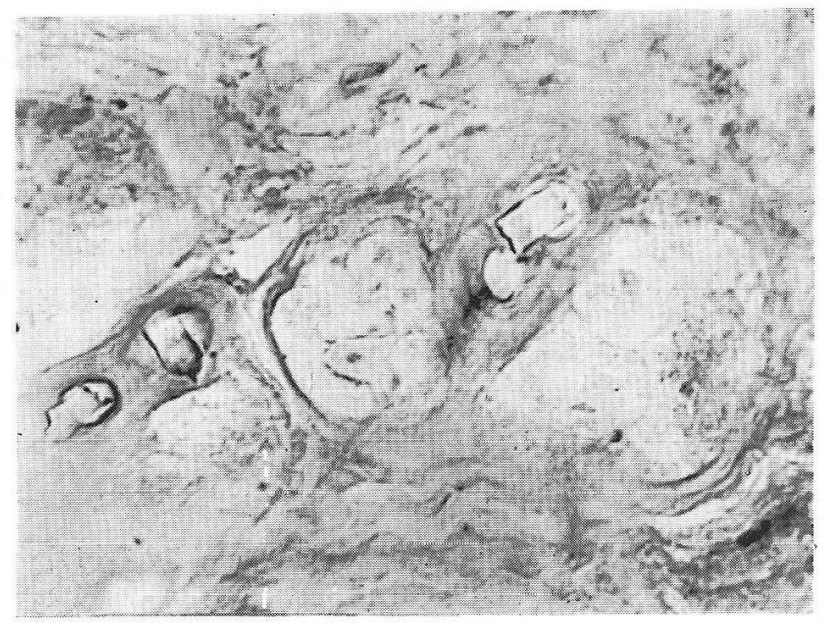

図1.二十日鼠背部の皮䖉。毛包の内面己毛の表西が势染する。脂線 の細胞は染らない。ホルマリン固定，カーボロックス包埋，ピタトリ ア清染色 (軽く核牢赫で後染). 拡大 900 倍。

Abb. 1. Aus der Rückenhaut der Maus. Die innere Fläche der Haarbalge und die Oberfläche der Haare sind intensiv mit Viktoriablau gefärbt, nicht aber dic Zellen der Talgdrüsen. Formalinfixierung, Einbettung in Carbowax, Viktoriablaufärbung des Schnittes und leichte Nachfärbung mit Kernech trot. $900 \times$.

脂腺の脲胞のけ央部で崩壊しつつある細胞忟粒了狀を呈しているが（図

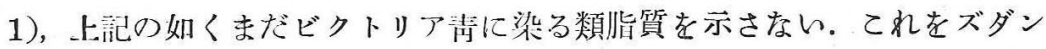
IIIーヘマトキシリン染色標本で見ると，腺胞り中央部には橙黃り物渋が見 られ，仔細に見れば，その物塊の中にはやはり橙黄色の数個の小さな光を

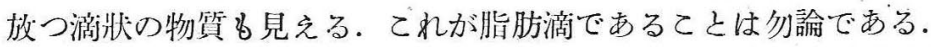

要するに，脂腺では多分類脂犋が脂肪に溶けていてビクトリヤ青では證 明せられず，毛包に出て始めてそれと分れ，一程度毛包上皮と毛に滲达 
み，證朋せられるようにな る.

\section{2. 表皮。}

刨斥で見ると，表皮り最

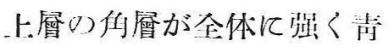
染し，肧芽葍は核年赤こビ クトリア青に潉染して紫を 呈する(図3). ズダンIIIヘマトキシリンで染めれ

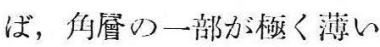
淡带に染るほかは, 㱠ざ全 休がへマトキシリンの紫に 染り, 肧芽層为全体が紫で ある。

緒言に舉げた小山(昭 3) は人之数種の動物の皮腐の 角層之辇芽層の細胞にコレ スラリンを認め，また古く Unna \& Golodetz (1909) 女生化学的にコレステリン に注目したが，私り上記の 観察によれば，表皮は淺殿 海ど强くビクトリア青に染 る物質を有して居り，乙れ はモ包から出を皮脂の類㸝

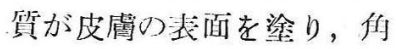
層に溶达んだものに垶いな 几. この類脂質は皮膚の㳖 猎にあつて異物の皮膚队一 の侵入を防ぐに役立つてと が推测せられる。

\section{B. 生きた動物の 皮膚表面の染色}

「材料と力法」で逝べた

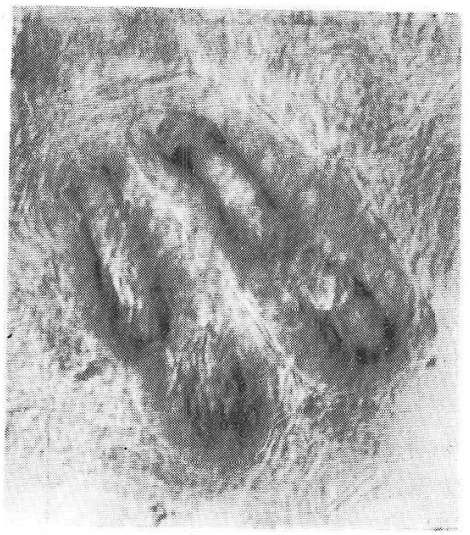

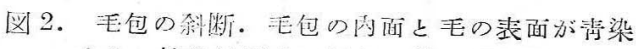
する。技衔は闵1に同じ。拡大 900 倍。

Abb. 2. Schräger Durchschnitt der Haarbalge. Die innere Fläche der Haarbalge und die Oberfläche der Hare sind stark gefärbt. Technik wie bei Abb. 1. $900 \times$.

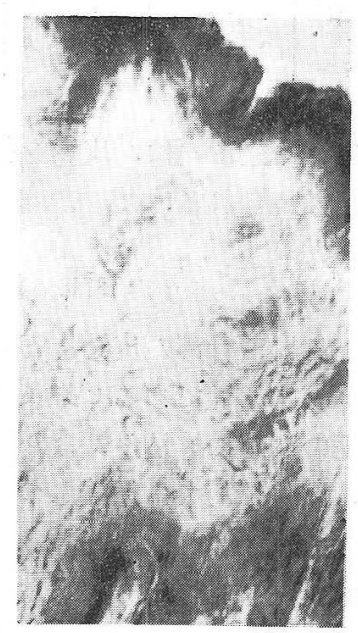

図3。翌皮の表曆が特によく青染する。毛包とモ の所見は図 2 と同栐である。技獄は図 1 に同じ。 昖大 900 倍。

Abb. 3. Die oberflächliche Schicht der Epidermis ist besonders gut gefärbt. Das Bild der Haarbalge und Haare ist wie in Abb. 2. Technik wie bei Abb. 1. $900 \times$. 


\begin{tabular}{|c|c|c|c|c|}
\hline & & 30 分 & 45 分 & 60 分 \\
\hline 頭 & 顶 & - & - & \pm \\
\hline 眼 & 瞼 & - & \pm & + \\
\hline \multicolumn{2}{|c|}{ 烦 } & - & - & \pm \\
\hline \multicolumn{2}{|c|}{ 鼻. } & - & \pm & + \\
\hline \multicolumn{2}{|c|}{ 口 } & - & - & \pm \\
\hline \multicolumn{2}{|c|}{ 耳: } & - & \pm & + \\
\hline 前 & 頸 & \pm & $\pm(+)$ & + \\
\hline 後 & 䫇 & - & - & \pm \\
\hline 背 & 部 & - & - & \pm \\
\hline & 部 & - & - & \pm \\
\hline & & - & $-( \pm)$ & + \\
\hline \multicolumn{2}{|c|}{ 腹 } & - & \pm & + \\
\hline 鼠 & 徑 & \pm & $\pm(+)$ & + \\
\hline \multicolumn{2}{|c|}{ 尾 } & - & $-( \pm)$ & \pm \\
\hline 後 & 䁌 & - & \pm & + \\
\hline 足 & 底 & - & - & - \\
\hline 前 & 肢 & - & \pm & + \\
\hline 手 & 等 & - & - & - \\
\hline \multicolumn{2}{|c|}{$\pi$} & \pm & + & + \\
\hline
\end{tabular}

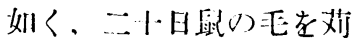
り,ビクトリア青溶液に 浴させ，身休の铚部分け

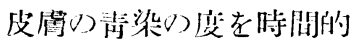
に見たが，結果は次り表 わ如くであつた。

皮虚け各部位り青染度 に著しい算は認められな いが，瓜の活かに，なお 前镍, 鼠徑, 胸, 腹门如く,

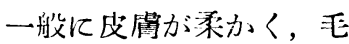
が㵣で且つ少い部位が比 較的早く，また良く㷙染 する. 即ちてれ等り部に は此較的類脂質が多いも のと思はれる。爪に就て は小山（昭 3 ）は爪編胞 と爪垢にコレステリンを 認めているが，爪代がク

トリア青によく染るのは，皮膚を搔くことにより爪に類脂質が滲込んでい るためと想像せられる。

\section{III. 結語.}

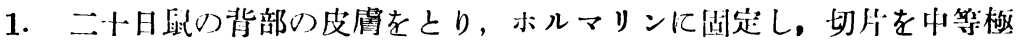
性でアルコール浴性であるビクトリア青にて染め, 青染する類脂質が甩包

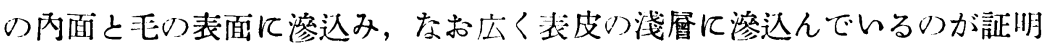
せられた．脂腺に於ては崩潰しつつある細胞にもまだ類脂質が分離してい なん,

2. 生きた二十日鼠をビクトリア其浴液に浴させると，爪のほかに、な お皮膚が青染するが，皮覻が柔かく，毛が軟で且つ少い部位が早く，また 良く青染し，即ちてれ等の部位に類脂質が比較的多く滲込んでいることが 知られる。

\section{Autoreferat.}

Formalinfixierte Hautstücke aus dem Rücken der Maus wurden 
mit einem mittelstark polaren, alkohollöslichen Farbstoff Viktoriablau gefärbt. Man sieht, daß die damit nachweisbaren Lipride die innere Fläche des Haarbalges, die Oberfläche des Haares, sowie die ober. flächliche Schicht der Epidermis tränken, während in den zerfallenden Zellen der Balgdrüsen die Lipoide nicht frei erscheinen.

Wenn man die Maus in einer Viktoriablaulösung baden läßt, so färbt sich außer dem Nagel diejenigen Hautbezirke rascher und besser, welche verhältnismäßig geschmeidig sind und weiche Harre lockerer tragen. Die Epidermis dieser Körpergegenden sind nämlich besser mit Lipoiden geschmiert.

\section{文献.}

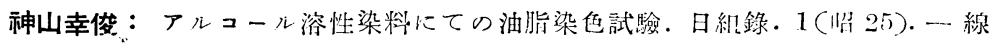

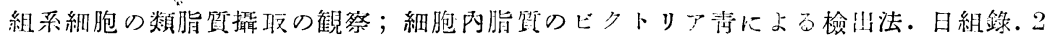

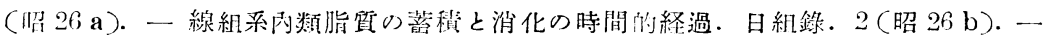

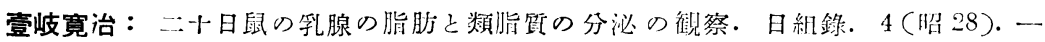

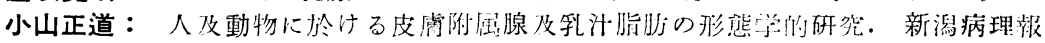
告. 7(临 3). - Unna, P. G. u. L. Golodelz: Die Hautfette. Biochenn. Z. 20 (1909). - Walter, H. : Über die Hautdrüsen mit lipoidsekretion bei Nagern. Zieglers Beitr. 7:(1924).一 山口正道：生体附に於けるコレステリン 新随代謝の研觉. 北越臣会钻. 39(大 $1: 3$ ). 